\title{
Targeted Therapy for Malignant Glioma Patients: Lessons Learned and the Road Ahead
}

\author{
Tiffany T. Huang, ${ }^{*}$ Shawn M. Sarkaria,* Timothy F. Cloughesy, ${ }^{\dagger *}$ and Paul S. Mischel*** \\ *Departments of Pathology and Laboratory Medicine and Molecular \& Medical Pharmacology and ${ }^{\dagger}$ Neurology, and the \\ ${ }^{\ddagger}$ Henry E. Singleton Brain Tumor Program, David Geffen School of Medicine, University of California, Los Angeles, \\ Los Angeles, California 90095
}

\begin{abstract}
Summary: Molecularly targeted therapies are transforming the care of patients with malignant gliomas, including glioblastoma, the most common malignant primary brain tumor of adults. With an arsenal of small molecule inhibitors and antibodies that target key components of the signal transduction machinery that are commonly activated in gliomas, neurooncologists and neurosurgeons are poised to transform the care of these patients. Nonetheless, successful application of targeted therapies remains a challenge. Strategies are lacking for directing kinase inhibitor or other pathway-specific therapies to individual patients most likely to benefit. In addition, response to targeted agents is determined not only by the presence of the key mutant kinases, but also by other critical changes in the molecular circuitry of cancer cells, such as loss of key tumor suppressor proteins, the selection for kinase-resistant mutants, and the deregulation of feedback loops. Understanding these
\end{abstract}

signaling networks, and studying them in patients, will be critical for developing rational combination therapies to suppress resistance for malignant glioma patients. Here we review the current status of molecular targeted therapies for malignant gliomas. We focus initially on identifying some of the insights gained to date from targeting the EGFR/PI3K/Akt/mTOR signaling pathway in patients and on how this has led toward a reconceptualization of some of the challenges and directions for targeted treatment. We describe how advances from the world of genomics have the potential to transform our approaches toward targeted therapy, and describe how a deeper understanding of the complex nature of cancer, and its adeptness at rewiring molecular circuitry to evade targeted agents, has raised new challenges and identified new leads. Key Words: Glioma, growth factors, molecular targeted therapy, microenvironment, coactivation.

\section{INTRODUCTION}

Molecularly targeted therapies are transforming the treatment of cancer. Instead of therapies based on relatively broad pathologic diagnoses, population-based risk assessments, and relatively nonspecific one-size-fits-all strategies, we are moving to an era of predictive care based on molecular classification and targeted kinase inhibitor therapies. The enthusiasm for molecularly targeted approaches to cancer treatment seems justified by the remarkable success of selected kinase inhibitors in the clinic for cancers such as chronic myeloid leukemia (CML) and gastrointestinal stromal tumor (GIST), and by an increasing ability to interrogate the cancer genome, transcriptome, and proteome in clinical tumor samples.

Address correspondence and reprint requests to: Paul S. Mischel, M.D., University of California, Los Angeles, 10833 Le Conte Avenue, Box 951732, Los Angeles, CA 90095. E-mail: pmischel@mednet. ucla.edu.
There is compelling evidence that activating mutations in signaling pathways can result in tumor cell addiction to these pathways and so allow the prediction of clinical responses to pathway inhibition.

The remarkable success of signal transduction inhibitors for the treatment of patients with CML and GIST has yet to translate to the treatment of patients with malignant gliomas. One potential explanation for the relative success lies in the fact that the relevant molecular targets (BCR-ABL and c-KIT mutations, respectively) are present in the overwhelming majority of CML and GIST patients. In contrast, in malignant gliomas many different molecular alterations are present in varying combinations, which cannot be readily detected by routine pathological examination. In fact, strategies are lacking for directing kinase inhibitor or other pathway-specific therapies to the individual patients most likely to benefit. In addition, response to kinase inhibitors is determined not only by the presence of the key mutant kinases, but also by other critical changes in the molecular circuitry of cancer cells, 
such as loss of key tumor suppressor proteins, the selection for kinase-resistant mutants, and the deregulation of feedback loops. Understanding these signaling networks, and studying them in patients, will be critical for developing rational combination therapies to suppress resistance for malignant glioma patients.

An arsenal of small molecule inhibitors and antibodies has been developed, and is continuing to be developed, to target key components of the signal transduction machinery, with a particular focus on growth factors and their corresponding receptors and canonical downstream signal transduction intermediates. Many of these inhibitors have potential for the treatment of glioblastoma. Testing some of these inhibitors, as well as using genetic approaches to untangling these signaling networks in well-designed model systems (including both highly representative xenograft models and mouse genetic models), is beginning to provide an emerging picture of the targetable molecular phenotype of glioblastoma. Complementary to these studies, application of powerful new technologies to interrogate molecular networks in clinical samples, particularly as applied to innovative clinical trials, has begun to yield important insights as to why (with the exception of the anti-VEGF antibody bevacizumab) targeted monotherapies have yet to significantly improve outcome for most patients with malignant gliomas. These insights are beginning to point the way toward alternative combination approaches that are more likely to yield effective treatments that can anticipate and suppress clinical resistance.

In this review, we set forth the rationale for targeting growth factors and their receptors and describe the challenges of translating an increasing knowledge of the underlying biology of gliomas into more successful treatments. We take as an example the lessons learned to date from targeting a paradigmatic example, the EGFR/PI3K/ $\mathrm{Akt} / \mathrm{mTOR}$ signaling network, in malignant glioma patients. We then discuss how a deeper understanding of canonical growth factor signaling networks commonly activated in malignant gliomas has opened up a range of other possibilities for targeted therapies. Finally, we conclude by setting forth a series of challenges, and suggest some potential approaches to developing more effective and less toxic treatments for patients with malignant gliomas.

\section{GROWTH FACTORS, THEIR RECEPTORS, AND DOWNSTREAM SIGNALING PATHWAYS AS TARGETS}

Self-sufficiency of growth signals is one of the classic hallmarks of cancer. ${ }^{1}$ Tightly linked to this phenotype are resistance to antigrowth signals, evasion of apoptosis, limitless replicative capacity, tumor invasion, and enhanced angiogenesis. All these classic hallmarks of can- cer are directly linked to deregulated growth factor receptor signaling. This should be no surprise: growth factor signaling in health is tightly regulated to orchestrate cell growth, cell division, and cell death. Genetic copy number alterations and mutations that activate growth factor signaling (e.g., common oncogene gains) or prevent negative regulation of their downstream effectors (e.g., common tumor suppressor losses) often result in persistently activated growth factor signaling networks that promote growth factor-independent proliferation, survival, invasion, and angiogenesis.

Activating mutations of growth factor receptors are, in fact, among the most common oncogenes; they were among the first to be identified, ${ }^{2}$ and studies of nonviral cancers clearly demonstrate that DNA amplification and mutation mediated activation of growth factor receptors are common events across many types of cancer, including malignant gliomas. In addition, growth factor receptor ligands such as epidermal growth factor (EGF), vascular endothelial growth factor (VEGF), platelet-derived growth factor (PDGF), and hepatocyte growth factor (HGF) are known to be upregulated in malignant gliomas. ${ }^{3-9}$

Growth factor receptors that are amplified and/or mutated make appealing drug targets. Their cell surface location, and abundant expression in many cancer cells, have facilitated the development of small molecule inhibitors that target these receptors, frequently as ATPcompetitive inhibitors (Table 1). In addition, the cell surface location makes them potential sites for antibodymediated therapies. For example, antibodies targeting a specific mutant form of EGFR, EGFRvIII (described in detail below) are already in clinical trials. Although the blood-brain barrier presents delivery issues for antibodies, numerous studies have suggested that the leaky barrier found in most gliomas does allow some access. ${ }^{10-13}$

Mutated growth factor receptors use a series of canonical signal transduction cascades to promote tumor growth, survival and invasion. The PI3K/Akt signaling pathway and the Ras/MAPK pathways, among others, have emerged as central players in glioma pathogenesis by promoting proliferation, inhibiting apoptosis, stimulating invasion, and leading to angiogenesis. ${ }^{14-16} \mathrm{As}$ described below, mouse genetic models provide compelling functional evidence for importance of these signaling networks in glioma pathogenesis, and correlative human studies attest to their relevance.

The real challenge is to do the clinical experiment. Does inhibition of these crucial signaling networks in malignant glioma patients result in tumor shrinkage, longer time to progression, and improved survival? Unfortunately, the initial series of clinical trials with small molecule inhibitors of EGFR and mTOR (as will be described in more detail below) failed to show efficacy, in part because there were no strategies in place to direct these therapies to the patients whose tumor molecular composi- 
Table 1. Drugs Targeting Growth Factors and Growth Factor Receptors

\begin{tabular}{|c|c|c|c|c|}
\hline Therapeutic Agent & Target(s) & Company & Comments and Status* & GBM Tr \\
\hline \multicolumn{5}{|l|}{ EGFR/ERBB family } \\
\hline Gefetinib (Iressa) ${ }^{69}$ & EGFR & AstraZeneca & $\begin{array}{l}\text { Selective EGFR inhibitor; phase II trials } \\
\text { for GBM demonstrated modest if any } \\
\text { clinical benefit; FDA approved for } \\
\text { NSCLC }\end{array}$ & Yes \\
\hline Erlotinib (Tarceva) ${ }^{70,71}$ & EGFR & Genentech & $\begin{array}{l}\text { Selective EGFR inhibitor; trials indicate } \\
\text { minimal efficacy as monotherapy for } \\
\text { GBM patients; ongoing trials in } \\
\text { combination with other drugs for } \\
\text { treatment of GBM; FDA approved for } \\
\text { NSCLC }\end{array}$ & Yes \\
\hline Lapatinib (Tykerb) & EGFR, ERBB2 & GlaxoSmithKline & $\begin{array}{l}\text { Dual inhibitor; phase II trials underway } \\
\text { for GBM; FDA approved for breast } \\
\text { cancer }\end{array}$ & Yes \\
\hline BMS-599626 72 & EGFR, ERBB2 & $\begin{array}{l}\text { Bristol-Myers } \\
\text { Squibb }\end{array}$ & $\begin{array}{l}\text { Dual inhibitor; phase I trials underway for } \\
\text { advanced solid tumors }\end{array}$ & No \\
\hline \multicolumn{5}{|l|}{ Anti-EGFR antibodies } \\
\hline Cetuximab (Erbitux) ${ }^{73}$ & EGFR & Eli Lilly/ImClone & $\begin{array}{l}\text { Chimeric extracellular-binding antibody; } \\
\text { small subgroup of patients responded in } \\
\text { phase II trial for GBM; trials underway } \\
\text { as a combination therapy; FDA } \\
\text { approved for colorectal cancer }\end{array}$ & Yes \\
\hline $\begin{array}{l}\text { Panitumumab } \\
(\text { Vectibix })^{74}\end{array}$ & EGFR & Amgen & $\begin{array}{l}\text { Human extracellular-binding antibody; } \\
\text { ongoing phase II trials for various solid } \\
\text { tumors; FDA approved for colorectal } \\
\text { cancer }\end{array}$ & No \\
\hline Nimotuzumab $^{75,76}$ & EGFR & YM BioSciences & $\begin{array}{l}\text { Humanized extracellular-binding antibody; } \\
\text { promising results from early trials; } \\
\text { phase II/III trials underway for GBM }\end{array}$ & Yes \\
\hline Matuzumab $^{77}$ & EGFR & Merck & $\begin{array}{l}\text { Humanized extracellular-binding antibody; } \\
\text { development in question due to poor } \\
\text { clinical trial results; may prove effective } \\
\text { as a combination therapy }\end{array}$ & No \\
\hline Zalutumumab $^{78}$ & EGFR & Genmab & $\begin{array}{l}\text { Human extracellular-binding antibody; } \\
\text { phase II trials for SCCHN in progress }\end{array}$ & No \\
\hline IMC-11F8 $8^{79,80}$ & EGFR & Eli Lilly/ImClone & $\begin{array}{l}\text { Fully human extracellular-binding } \\
\text { antibody; phase II trial for colorectal } \\
\text { cancer in progress }\end{array}$ & No \\
\hline MAb $806(\mathrm{Ch} 806)^{81}$ & EGFR & & $\begin{array}{l}\text { Chimeric extracellular-binding antibody } \\
\text { that preferentially targets EGFRvIII and } \\
\text { active EGFR; phase I trial complete }\end{array}$ & Yes \\
\hline \multicolumn{5}{|l|}{ Anti-ERBB2 antibodies } \\
\hline $\begin{array}{l}\text { Trastuzumab } \\
{\text { (Herceptin })^{82}}^{82}\end{array}$ & ERBB2 & Genentech & $\begin{array}{l}\text { Humanized extracellular-binding antibody; } \\
\text { induces glioma cell death in preclinical } \\
\text { study; FDA approved for breast cancer }\end{array}$ & No \\
\hline Pertuzumab (Omnitarg) & ERBB2 & Genentech & $\begin{array}{l}\text { Humanized extracellular-binding antibody; } \\
\text { interferes with receptor dimerization; } \\
\text { ongoing phase II/III trials for breast } \\
\text { cancer }\end{array}$ & No \\
\hline \multicolumn{5}{|l|}{ Anti-IGF-1R antibodies } \\
\hline AMG- $479^{83}$ & IGF-1R & Amgen & $\begin{array}{l}\text { Human extracellular-binding antibody; } \\
\text { combined therapy phase I/II trials are } \\
\text { starting for solid tumors }\end{array}$ & No \\
\hline IMC-A $12^{84,85}$ & IGF-1R & Eli Lilly/ImClone & $\begin{array}{l}\text { Human extracellular-binding antibody; } \\
\text { several phase II trials underway for } \\
\text { solid tumors }\end{array}$ & No \\
\hline
\end{tabular}

(Table continues) 
Table 1. Continued

\begin{tabular}{|c|c|c|c|c|}
\hline Therapeutic Agent & Target(s) & Company & Comments and Status* & GBM Trial \\
\hline CP-751,871 86,87 & IGF-1R & Pfizer & $\begin{array}{l}\text { Humanized extracellular-binding antibody; } \\
\text { phase I/II trails ongoing for a variety of } \\
\text { solid tumors; encouraging results in } \\
\text { combination with chemotherapy for } \\
\text { NSCLC }\end{array}$ & No \\
\hline \multicolumn{5}{|l|}{ HGF/MET antagonists } \\
\hline $\mathrm{NK} 4^{88}$ & MET & Kringle Pharma & $\begin{array}{l}\text { Competitively inhibits HGF binding to } \\
\text { MET; proven efficacy in GBM } \\
\text { preclinical studies }\end{array}$ & No \\
\hline Uncleavable $\mathrm{HGF}^{89}$ & MET, HGF & & $\begin{array}{l}\text { Immune to protease activation yet binds } \\
\text { MET; antitumor activity in preclinical } \\
\text { development }\end{array}$ & No \\
\hline $\begin{array}{l}\text { Recombinant Sema } \\
\text { domain }^{90}\end{array}$ & MET, HGF & Genentech & $\begin{array}{l}\text { Extracellular domain of MET binds HGF } \\
\text { and interferes with MET dimerization; } \\
\text { antitumor activity in preclinical } \\
\text { development }\end{array}$ & No \\
\hline Decoy MET $^{91}$ & MET, HGF & & $\begin{array}{l}\text { Soluble extracellular portion of MET } \\
\text { receptor; antitumor activity in } \\
\text { preclinical development }\end{array}$ & No \\
\hline Cgen-241 92 & MET, HGF & Compugen & $\begin{array}{l}\text { MET ectodomain/IgG fusion protein; } \\
\text { preclinical study demonstrated } \\
\text { antiproliferative effect on GBM cells }\end{array}$ & No \\
\hline \multicolumn{5}{|l|}{ Anti-HGF/SF antibodies } \\
\hline $\mathrm{L} 2 \mathrm{G} 7^{93}$ & $\mathrm{HGF}$ & Galaxy Biotech & $\begin{array}{l}\text { HGF neutralizing antibody; effective in a } \\
\text { preclinical GBM model }\end{array}$ & No \\
\hline AMG $102^{94}$ & HGF & Amgen & $\begin{array}{l}\text { Fully human HGF neutralizing antibody; } \\
\text { phase II trial for GBM is ongoing and } \\
\text { preliminary data indicate some cases of } \\
\text { clinical benefit }\end{array}$ & Yes \\
\hline \multicolumn{5}{|l|}{ Anti-MET antibodies } \\
\hline OA-5D5 (MetMAb) & MET & Genentech & $\begin{array}{l}\text { Humanized extracellular-binding antibody; } \\
\text { inhibits GBM tumor growth in } \\
\text { preclinical study; planning phase II trial } \\
\text { for NSCLC }\end{array}$ & No \\
\hline CE-355621 96 & MET & Pfizer & $\begin{array}{l}\text { Extracellular-binding antibody; effective } \\
\text { in preclinical GBM study }\end{array}$ & No \\
\hline $\mathrm{DN}-30^{97}$ & MET & Metheresis & $\begin{array}{l}\text { Extracellular-binding antibody; impairs } \\
\text { GBM tumor growth in a preclinical } \\
\text { study }\end{array}$ & No \\
\hline \multicolumn{5}{|l|}{ MET kinase inhibitors } \\
\hline $\mathrm{AM} 7^{98}$ & $\begin{array}{l}\text { MET, LCK, } \\
\text { BTK }\end{array}$ & Amgen & $\begin{array}{l}\text { Effective against several mutant forms of } \\
\text { MET; efficacy demonstrated in GBM } \\
\text { preclinical model }\end{array}$ & No \\
\hline ARQ $197^{99,100}$ & MET & ArQule & $\begin{array}{l}\text { Selective MET inhibitor; phase I/II trials } \\
\text { in progress for advanced solid tumors }\end{array}$ & No \\
\hline MK-2461 ${ }^{101}$ & MET & Merck & $\begin{array}{l}\text { Selective MET inhibitor; ongoing phase } \\
\text { I/II trials for advanced solid tumors }\end{array}$ & No \\
\hline MP470 102 & $\begin{array}{l}\text { MET, PDGFR, } \\
\text { KIT }\end{array}$ & SuperGen & $\begin{array}{l}\text { Multikinase inhibitor that also stifles DNA } \\
\text { repair by suppressing Rad51; preclinical } \\
\text { studies in GBM; ongoing phase I trial } \\
\text { for solid tumors }\end{array}$ & No \\
\hline JNJ-38877605 & MET & Johnson \& Johnson & $\begin{array}{l}\text { Selective MET inhibitor; phase I trial } \\
\text { underway for advanced solid tumors }\end{array}$ & No \\
\hline PF-2341066 ${ }^{103}$ & MET, ALK & Pfizer & $\begin{array}{l}\text { Potent MET and ALK inhibitor; ongoing } \\
\text { phase I/II trials for stomach tumors and } \\
\text { lymphomas }\end{array}$ & No \\
\hline PHA665752 $2^{104}$ & MET & Pfizer & $\begin{array}{l}\text { Selective MET inhibitor; abrogates } \\
\text { signaling in preclinical setting }\end{array}$ & No \\
\hline
\end{tabular}


Table 1. Continued

\begin{tabular}{|c|c|c|c|c|}
\hline Therapeutic Agent & Target(s) & Company & Comments and Status* & GBM Trial \\
\hline SU11274 $4^{58,105,106}$ & MET & Pfizer & $\begin{array}{l}\text { Selective MET inhibitor effective against } \\
\text { several mutant variants of MET; potent } \\
\text { antagonist in GBM cell lines }\end{array}$ & No \\
\hline XL880/GSK1363089 107 & MET, VEGFR2 & Exelixis & $\begin{array}{l}\text { Multikinase inhibitor that primarily targets } \\
\text { MET and VEGFR2; phase I trials for } \\
\text { solid tumors; phase II trials for PRC, } \\
\text { SCCHN and gastric cancer }\end{array}$ & No \\
\hline XL184 ${ }^{108}$ & $\begin{array}{l}\text { MET, VEGFR2, } \\
\text { RET }\end{array}$ & Exelixis & $\begin{array}{l}\text { Multikinase inhibitor; phase II trial } \\
\text { underway for GBM }\end{array}$ & Yes \\
\hline \multicolumn{5}{|l|}{ PDGFR kinase inhibitors } \\
\hline Dasatinib (Sprycel) ${ }^{109}$ & $\begin{array}{c}\text { PDGFR, SFKs, } \\
\text { BCR-ABL }\end{array}$ & $\begin{array}{l}\text { Bristol-Myers } \\
\text { Squibb }\end{array}$ & $\begin{array}{l}\text { Potent inhibitor of many kinases; } \\
\text { promising preclinical data; phase I/II } \\
\text { trials underway for GBM; FDA } \\
\text { approved for CML }\end{array}$ & Yes \\
\hline Imatinib (Gleevec) $)^{110-113}$ & $\begin{array}{c}\text { PDGFR, KIT, } \\
\text { BCR-ABL }\end{array}$ & Novartis & $\begin{array}{l}\text { Multikinase inhibitor; limited antiglioma } \\
\text { activity as monotherapy; effect in some } \\
\text { GBM patients when combined with } \\
\text { hydroxyurea; phase I/II trials in } \\
\text { combination with other drugs are } \\
\text { ongoing; FDA approved for CML and } \\
\text { GIST }\end{array}$ & Yes \\
\hline Tandutinib & $\begin{array}{l}\text { PDGFR, FLT3, } \\
\text { KIT }\end{array}$ & $\begin{array}{l}\text { Millennium } \\
\text { Pharmaceuticals }\end{array}$ & $\begin{array}{l}\text { Multikinase inhibitor; phase II trial in } \\
\text { combination with Avastin underway }\end{array}$ & Yes \\
\hline \multicolumn{5}{|l|}{ VEGF antibodies } \\
\hline $\begin{array}{l}\text { Bevacizumab } \\
\text { (Avastin) }^{114,115}\end{array}$ & VEGF & Genentech & $\begin{array}{l}\text { Humanized VEGF neutralizing antibody; } \\
\text { several phase II trials have reported } \\
\text { significant antiglioma activity; many } \\
\text { ongoing trials are combining Avastin } \\
\text { with other therapeutic agents; FDA } \\
\text { approved for previously treated GBM }\end{array}$ & Yes \\
\hline \multicolumn{5}{|l|}{ VEGF antagonists } \\
\hline $\begin{array}{l}\text { Aflibercept/VEGF } \\
\text { Trap }^{116,117}\end{array}$ & VEGF & Regeneron & $\begin{array}{l}\text { VEGFR ectodomain/IgG fusion protein; } \\
\text { phase II trial found single-agent efficacy } \\
\text { in GBM; combined therapy trials } \\
\text { imminent }\end{array}$ & Yes \\
\hline \multicolumn{5}{|l|}{ VEGFR kinase inhibitors } \\
\hline $\begin{array}{l}\text { Cediranib/AZD2171 } \\
\text { (Recentin) }^{118,119}\end{array}$ & $\begin{array}{l}\text { VEGFR, } \\
\text { PDGFR, KIT, } \\
\text { FGFR1 }\end{array}$ & AstraZeneca & $\begin{array}{l}\text { Most potent against VEGFR; phase II trial } \\
\text { showed promising GBM tumor } \\
\text { responses; phase II/III trials are } \\
\text { underway in combination with cytotoxic } \\
\text { therapy }\end{array}$ & Yes \\
\hline Pazopanib $^{120}$ & $\begin{array}{l}\text { VEGFR, } \\
\text { PDGFR, KIT }\end{array}$ & GlaxoSmithKline & $\begin{array}{l}\text { Multikinase inhibitor; promising phase } \\
\text { II/III results for RCC; phase II trials in } \\
\text { progress for GBM and other solid } \\
\text { tumors }\end{array}$ & Yes \\
\hline Sorafenib (Nexavar) ${ }^{121}$ & $\begin{array}{l}\text { VEGFR, c-Raf, } \\
\text { B-Raf, } \\
\text { PDGFR }\end{array}$ & Bayer & $\begin{array}{l}\text { Multikinase inhibitor; combined with } \\
\text { other targeted therapies in ongoing } \\
\text { phase II trials for GBM; FDA approved } \\
\text { for RCC }\end{array}$ & Yes \\
\hline Sunitinib (Sutent) & $\begin{array}{l}\text { VEGFR, } \\
\text { PDGFR, KIT, } \\
\text { RET, FLT3 }\end{array}$ & Pfizer & $\begin{array}{l}\text { Multikinase inhibitor; several phase II } \\
\text { trials underway for GBM; FDA } \\
\text { approved for RCC and GIST }\end{array}$ & Yes \\
\hline $\begin{array}{l}\text { Vandetanib/ } \\
\text { ZD6474 }\end{array}$ & VEGFR, EGFR & AstraZeneca & $\begin{array}{l}\text { Dual inhibitor; phase I/II trials in progress } \\
\text { for GBM; mixed results from other } \\
\text { solid tumor trials; candidate for } \\
\text { combination therapy }\end{array}$ & Yes \\
\hline
\end{tabular}

(Table continues) 
Table 1. Continued

\begin{tabular}{llll}
\hline Therapeutic Agent & Target(s) & Company & Comments and Status* \\
\hline Vatalanib/PTK787 & $\begin{array}{c}\text { VEGFR, } \\
\text { PDGFR, KIT }\end{array}$ & Novartis & $\begin{array}{c}\text { Most potent against VEGFR; phase I/II } \\
\text { trials ongoing for GBM; encouraging } \\
\text { results as combination therapy }\end{array}$ \\
\hline
\end{tabular}

$\mathrm{ALK}=$ anaplastic lymphoma kinase; BCR-ABL = a gene fusion protein product; B-Raf = a proto-oncogenic kinase; BTK $=$ Bruton's tyrosine kinase; $\mathrm{CML}=$ chronic myeloid leukemia; $\mathrm{c}$-Raf $=$ a protein kinase involved in MAPK pathway; EGFR = epidermal growth factor receptor; ERBB2 = a member of the epidermal growth factor (EGF) receptor family; FDA = U.S. Food and Drug Administration; FGFR1 = fibroblast growth factor receptor 1; FLT3 = fms-related tyrosine kinase 3; GBM = glioblastoma multiforme; GIST = gastrointestinal stromal tumor; HGF/SF = hepatocyte growth factor/scatter factor; IGF-1R = insulin-like growth factor receptor type 1; $\mathrm{IgG}=$ immunoglobulin $\mathrm{G}$; KIT = a protein-tyrosine kinase receptor specific for stem cell factor; LCK = lymphocyte specific protein tyrosine kinase p56(lck); MET = cell surface protein-tyrosine kinase receptor for hepatocyte growth factor; NSCLC = non-small cell lung cancer; PDGFR $=$ platelet-derived growth factor receptor; PRC $=$ papillary renal-cell carcinoma; Rad51 $=$ repairs DNA double strand breaks; $\mathrm{RCC}=$ renal cell carcinoma; RET $=$ a receptor protein-tyrosine kinase involved in signaling of glial cell-line derived neurotrophic factor ligands; SCCHN = squamous cell cancer of the head and neck; SFK = Src family kinases; VEGF(R) = vascular endothelial growth factor (receptor).

*Status reflects progress in the treatment of gliomas when applicable. Agents may be further along for other malignancies. Refer to http://www.clinicaltrials.gov for more detailed information.

tion was most likely to yield a favorable response. Furthermore, even in patients fortunate enough to have a clinical response, for most of them the duration of response was limited. This should not be considered evidence of the lack of feasibility of effective targeted therapy. Rather, it must be considered a humbling lesson in our relative lack of understanding of the remarkable capacity of cancer cells to adapt and rewire to overcome targeted monotherapy.

An analogy with the development of combination antiretroviral therapy for HIV is apt. The first attempts in treatment of HIV with antiretroviral therapy yielded excitement, but then disappointment, as patients rapidly failed monotherapy. However, careful analysis of the mechanisms of resistance was critical for developing rational combination therapies that anticipate and suppress resistance, an achievement that has transformed a deadly disease into a chronic one that can be managed. The future of targeted therapies hinges on understanding how the molecular circuitry rewires to promote resistance, and then developing combination therapies to more effectively suppress it.

\section{DEFINING CORE PATHWAYS IN GBM: HIGH-THROUGHPUT TECHNOLOGIES TO INTERROGATE THE MUTATIONAL LANDSCAPE OF PATIENT SAMPLES MEET FUNCTIONAL BIOLOGY}

The application of powerful technologies to globally survey the genome, transcriptome, and epigenome of human cancer samples has greatly increased our knowledge of the molecular underpinnings of malignant glioma and has provided a striking concordance with lessons learned from mouse genetic models. Two recent large-scale multidimensional analyses of glioblastoma shed light on the mutational landscape of glioblastoma. The studies by the Cancer Genome Atlas (TCGA) group ${ }^{17}$ and by Parsons et al. ${ }^{18}$ through integrated anal- yses of multidimensional genomic data from complementary technology platforms identified three core genetically altered pathways: 1) RTK/RAS/PI3K, 2) p53, and 3) RB, which are present in nearly all glioblastomas. These studies offer the promise that application of global methods can identify previously unrecognized molecular targets, and the convergence of findings upon these three signaling networks further highlights their importance. Mouse genetic models also have strongly implicated these pathways. ${ }^{19-27}$ Furthermore, activation of these pathways has also been detected and maintained in elegant, serially passaged human glioblastoma intracranial xenograft models. ${ }^{28}$

RTK/RAS/PI3K pathway activation appears to be an obligatory event in most, and perhaps all, glioblastomas. ${ }^{17,18}$ This observation is entirely consistent with previous studies that have used less global approaches to analyzing this signaling network in clinical samples from glioblastoma patients. ${ }^{29-31}$

\section{THE EGFR/PI3K/AKT/mTOR SIGNALING NETWORK: A PARADIGMATIC EXAMPLE}

In malignant gliomas, EGFR amplification and mutation is by far the most common receptor tyrosine kinase (RTK) alteration. ${ }^{17,18}$ EGFR amplification and/or mutation, in combination with loss of the PTEN tumor suppressor protein, results in constitutive PI3K pathway activation, which highlights the role of this signaling network as a molecular target. Normally, EGFR dimerizes and autophosphorylates to activate signal transduction through PI3K, MAPK, and other pathways upon binding to one of its two main ligands, EGF and transforming growth factor- $\alpha$ (TGF- $\alpha$ ). These ligands have been shown to be upregulated in glioblastoma, suggesting one possible mechanism for their activation. ${ }^{32-37}$ However, EGFR is most frequently activated in malignant gliomas through DNA amplification, which occurs in up to 
$45 \%$ of cases. ${ }^{17,18}$ In addition, activating mutations in the extracellular domain are common, including the most frequent form of activation, the EGFRvIII variant. ${ }^{32,34,36}$ This variant results from genomic deletion of exons 2-7; it is detected in between $20 \%$ and $30 \%$ of glioblastomas. ${ }^{17,18,38}$ It lacks the ligand-binding domain, yet also fails to be internalized regularly, resulting in a constitutive signal. A number of studies have suggested that EGFRvIII has a particularly strong effect on PI3K signaling, ${ }^{29}$ and recent proteomic studies suggest that EGFRvIII favors different canonical pathways relative to wild-type EGFR, including a greatly enhanced effect on PI3K pathway activation. ${ }^{39}$ In addition to EGFRvIII, genomic studies have identified a number of other genomic deletion variants, ${ }^{40,41}$ and recent work identifies a series of novel extracellular domain missense mutations, occurring in up to $14 \%$ of glioblastoma patients, that appear to be associated with gain of function. ${ }^{42}$

Thus, in glioblastoma, EGFR, potentially through its activation of the PI3K and MAPK pathways, and potentially through other less well understood signaling cascades, regulates tumor proliferation and growth, leads to growth factor independence, ${ }^{43}$ inhibits apoptosis, ${ }^{44,45}$ increases invasion, ${ }^{46}$ and promotes angiogenesis. ${ }^{44}$ The relevance of constitutive EGFR signaling for all of these hallmarks of cancer, coupled with its relatively high frequency in malignant gliomas, has suggested that EGFR could be for glioblastoma what BCR-ABL has become for chronic myeloid leukemia.

\section{TARGETING EGFR IN THE CLINIC: IT'S NOT SO SIMPLE}

The ability to target EGFR with ATP-competitive small molecule inhibitors such as erlotinib and gefitinib generated great excitement in the neuro-oncology community. Regrettably, the experience to date has not lived up to the promise. Clinical responses have been infrequent, and short-lived. This does not mean, however, that EGFR is not a compelling target, or even that glioblastoma cells are not addicted to it.

A number of lessons have been learned from this clinical experience. First, perhaps the most critical lesson from the first forays into targeted therapies for malignant glioma patients is that tumor cell responses are determined not only by the presence of the target, but rather also by the molecular circuitry in which these activating mutations occur. This concept of context-dependent oncogene addiction has important implications for the design of molecularly targeted combination therapies (as will be discussed below). Second, unlike cytotoxic agents, for which maximal tolerated dose can be used as a guide for determining effective drug dose, targeted agents require a different type of evaluation. Biomarkers of pathway inhibition need to be developed and incor- porated into clinical trial design in order to determine whether the study dose effectively inhibits its target in patients. It would be premature and misleading to assume that a target is not valid if our inhibitors have not achieved necessary inhibition of it in vivo. Third, pathways are not simply linear vectors moving from one molecule to the next, but rather complex interactive networks characterized by cross-talk and homeostatic feedback loops that can greatly influence response to therapy. Fourth, cancer cells are characterized by genomic instability, which favors mutations. Cancer patients are treated with cytotoxic agents and radiotherapy, which accelerate the rate of mutagenesis, and they are then subject to immense selection pressures as we treat them with targeted and nontargeted agents. Thus, a broader view of the ecology of the cancer system is needed. The initial experience with EGFR/PI3K pathway targeted therapies has been informative with regard to each of these points.

\section{LESSON 1: CONTEXT-DEPENDENT ONCOGENE ADDICTION}

Initial results with the EGFR tyrosine kinase inhibitors gefitinib and erlotinib suggested relatively low response rates, on the order of $10 \%$ to $15 \% .^{47,48}$ This was difficult to reconcile with the perceived importance of the EGFR target, and two important studies have shed light on this problem. Work from our group demonstrated that expression of the constitutively active mutant EGFRvIII sensitized tumors to EGFR inhibitors in vitro, and also in patients on clinical trials, but only if the PTEN tumor suppressor protein was intact. In fact, loss of PTEN uncoupled the inhibition of EGFR from the inhibition of downstream PI3K signaling, demonstrating that PTEN loss was a critical factor in promoting up-front resistance to EGFR inhibitors. ${ }^{49}$ Concurrently, Haas-Kogan et al. ${ }^{47}$ demonstrated, in vitro and in glioma patients, that high levels of EGFR coupled with low levels of activated Akt (a critical effector of PI3K signaling) were associated with favorable response. These two studies demonstrated that intact regulation of PI3K signaling appears to be critical for effective response to EGFR, a finding that has also been shown in the human serially passaged xenograft system. ${ }^{28}$ Furthermore, recent work by Fan et al. ${ }^{14}$ clearly demonstrates that EGFR signaling through PI3K, particularly through mTOR, is critical for mediating the response to EGFR tyrosine kinase inhibitors.

These findings all teach a critical lesson, that there are many paths toward resistance, whereas a few critical mediators must be inhibited for sensitivity. Perhaps EGFRvIII and PTEN expression, can potentially be used as biomarkers to identify patients more likely to respond to EGFR inhibitors (a large prospective trial through the RTOG is ongoing to test this hypothesis). However, it is 
likely that additional mechanisms of resistance will be present. It will be important to determine whether these resistance factors maintain constitutive PI3K signaling despite EGFR inhibition, to determine whether mTOR signaling will provide an accessible biomarker of response to EGFR kinase inhibitors.

\section{LESSON 2: BIOMARKERS OF PATHWAY INHIBITION NEED TO BE DEVELOPED AND INCORPORATED INTO CLINICAL TRIAL DESIGN}

The observation that successful inhibition of EGFR signaling is associated with suppression of mTOR activity suggested the possibility that dual EGFR/mTOR inhibition could be used to target EGFR-activated, PTENdeficient tumors. A number of studies have demonstrated the efficacy of this approach in model systems. ${ }^{50,51}$ However, early clinical trials with the mTOR complex inhibitor rapamycin and its derivatives did not show impressive clinical responses. ${ }^{48,52}$ Our group completed and published a clinical trial of the mTOR inhibitor rapamycin in patients with relapsed, PTEN-deficient glioblastomas and identified key determinants of sensitivity and resistance. ${ }^{53} \mathrm{We}$ showed that: 1$)$ the mTOR inhibitor rapamycin is present in potentially therapeutic levels in tumor tissue in vivo; that 2) rapamycin significantly inhibits mTOR signaling in all patients although the extent of inhibition is variable (from $10 \%$ to $80 \%$ pathway inhibition) and that 3) the extent of pathway inhibition is critical. mTOR pathway inhibition of greater than 50\% resulted in significantly inhibited proliferation; lower levels of mTOR inhibition did not translate into biological or clinical response. We further showed that this was not due to cell intrinsic resistance, but more likely was associated with failure of the drug to fully access its target in vivo. ${ }^{53}$ These results, leveraging a novel biopsytreat-biopsy paradigm, facilitated analysis of the effects of the inhibitor in patients leading to a critical lesson: target signaling may be insufficiently suppressed in vivo.

\section{LESSON 3: CROSS-TALK AND FEEDBACK LOOPS COMPLICATE TARGET SELECTION}

mTOR is an unusually important integrator of multiple signaling cascades. It mediates signaling through the canonical PI3K pathway via two distinct complexes, mTORC1 (in which mTOR is paired with raptor within the protein complex) and mTORC2 (in which mTOR is paired with rictor within the protein complex) to mediate cell growth and proliferation. mTORC1 uniquely integrates growth factor signaling through S6K1 with cellular metabolism, underscoring its value as a cancer target. ${ }^{54}$ mTORC1 signaling through S6K1 has recently been identified as a critical step in glial transformation. ${ }^{55}$ mTORC2 regulates Akt signaling in a rapamycin-insensitive fashion, placing mTOR as both a downstream target and an upstream activator of Akt (FIG. 1). ${ }^{56}$ Thus,

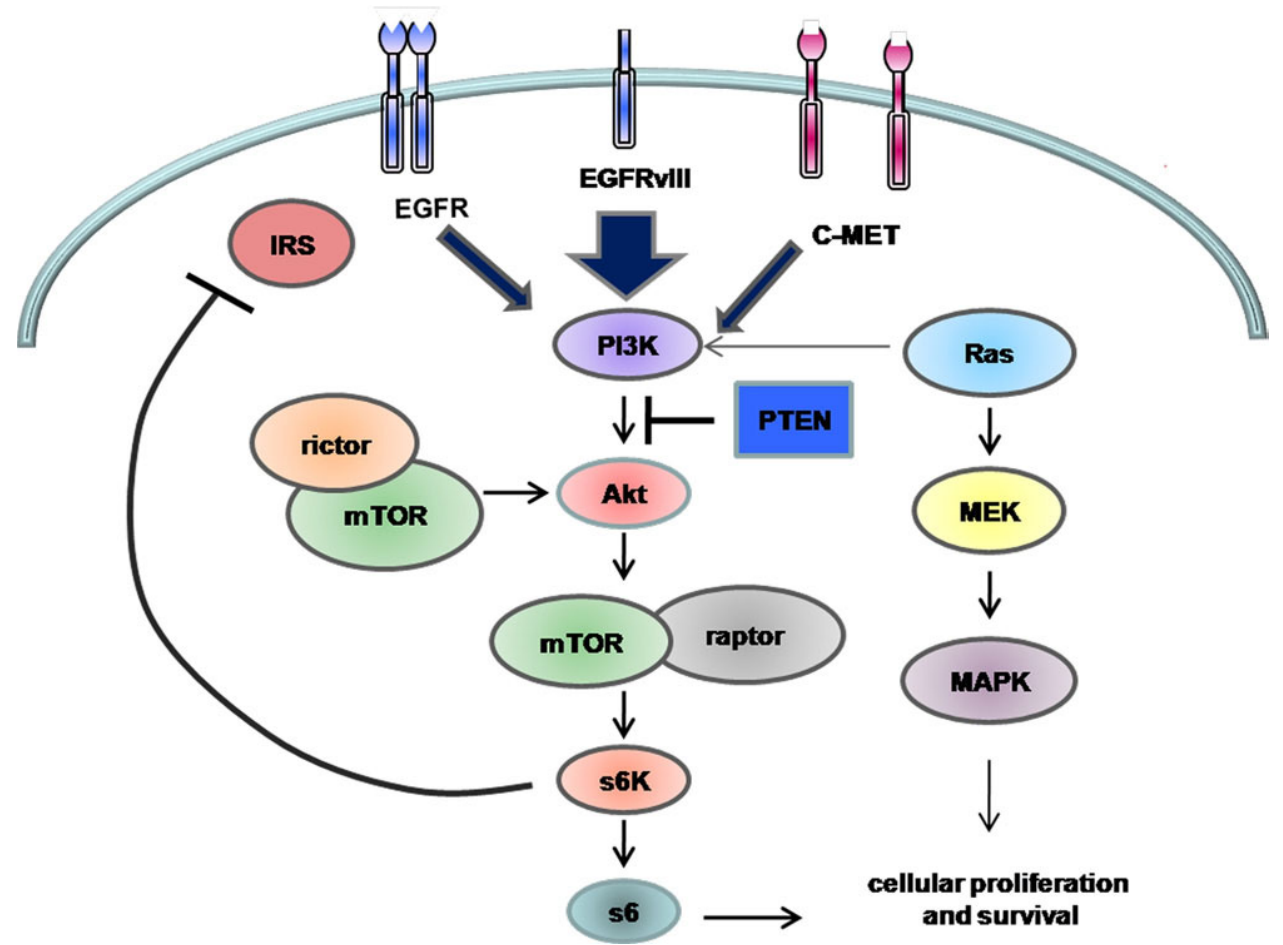

FIG. 1. The EGFR/PI3K/Akt/mTOR signaling pathway. The complexity of the signaling cascade is demonstrated by mTOR. Depending on its binding partner, raptor or rictor, the complex can be both a downstream target and an upstream activator of Akt. 
mTOR is part of a complex, nonlinear canonical signaling network. Furthermore, S6K1, the key downstream effector of mTORC1, is known to regulate a homeostatic negative regulatory loop inhibiting PI3K signaling via IRS when mTORC1 activity is high.

Our group demonstrated that rapamycin treatment in glioblastoma patients results in S6K1 inhibition, which releases the negative feedback, leading to PI3K activation at the level of Akt and resulting in more rapid clinical progression. ${ }^{53}$ Furthermore, recent studies from Pandolfi's group have shown that inhibition of mTOR signaling can activate the MAPK pathway, ${ }^{57}$ highlighting the plasticity of the cancer circuitry in evading response to targeted monotherapy. It will be important to determine whether similar effects are seen in malignant glioma patients, and, if so, to develop combination approaches to suppress it.

\section{LESSON 4: CANCER IS A MICROVENVIRONMENT OF ADAPTATION, MUTATION, AND SELECTION}

Some PTEN-intact malignant glioma patients relapse after enjoying a relatively short window of clinical response to EGFR kinase inhibitors. Recent work by DePinho's group sheds light on an alternative mechanism of acquired resistance. Notably, Stommel et al. ${ }^{58}$ demonstrated that other receptor tyrosine kinases such as cMET and PDGFR are commonly coactivated with EGFR and that when treated with EGFR inhibitors, c-MET and/or PDGFR engage PI3K to maintain downstream pathway activation despite EGFR inhibition. This suggests an noteworthy model in which nongenetic adaptations in the tumor result in resistance to treatment. Studies to assess this phenomenon in clinical samples from patients treated with EGFR inhibitors will be important for extending this model; however, these findings raise the concept that multiple inhibitors will be needed to suppress resistance. This is consistent with the lessons from pathway cross-talk and feedback described above. Thus, multiple lines of evidence are converging on the idea that successful targeted therapy will require carefully designed combinations of inhibitors with the objective of minimizing toxicity while maximizing benefit, based on an informed anticipation of mechanisms of resistance.

Borrowing again from lessons learned in treating CML patients with imatinib, the cancer community has recognized that rare secondary mutations in the kinase domain of BCR-ABL are selected for during imatinib treatment, leading to clinical resistance. A similar phenotype has been found in EGFR inhibitor-resistant lung cancer with detection of analogous mutations in the kinase domain of the receptor. It is not yet known whether such mutations are common in patients treated with
EGFR-inhibitors. If so, this strongly suggests the need to develop compounds that can inhibit such mutant kinases. Furthermore, it remains to be determined whether resistance is mediated by multiple mechanisms, including selection for kinase inhibitor-resistant mutations, and/or through adaptations such as pathway cross-talk or kinase switching. Understanding these escape routes will be essential for anticipating resistance and developing combination therapies to suppress it.

It is recognized that malignant gliomas are highly heterogeneous, and that selection for subpopulations of tumor cells, such as cancer stem cells, ${ }^{59-62}$ may be critical for therapeutic resistance. PTEN loss in gliomas is heterogeneous. It will be important to determine whether acquired resistance to EGFR inhibitors can be mediated by selection against EGFR-activated, PTEN-intact tumor cells. New tools are needed to facilitate single-cell analysis of key mutations and pathways and that can be used to profile the dynamic changes within the tumor environment during treatment.

\section{TARGETING MULTIPLE CORE PATHWAYS}

This review has focused primarily on growth factor signaling pathways through the PI3K and MAPK signaling networks. Mutational landscape studies, however, as well as previous population-based targeted mutational analyses, highlight the co-occurrence of p53 pathway and $\mathrm{Rb}$ pathway mutations in EGFR/PI3K-activated tumors (highlighted, for example, by some of the mouse models). ${ }^{24-27}$ Growth factor signaling has provided an attractive therapeutic target because it is easier to use small molecule inhibitors and antibodies to target a gainof-function molecule. In contrast, p53 and RB1 loss are less amenable, although a variety of small molecules that modulate signaling through both of these pathways are under investigation. ${ }^{63-66}$ Will it be necessary to concurrently target these pathways along with targeting the RTK/RAS/PI3K signaling network? Future studies will be needed. In addition, there may be efficacy in combining pathway-targeted therapies with other agents such as immunotherapies, radiotherapy, and chemotherapy, all of which are currently under investigation. Parsa et al. ${ }^{67}$ showed that mTOR, the same signaling pathway that is critical for RTK/RAS/PI3K core pathway activation, may also be a key regulator of the immune response, suggesting a possible benefit from combining small molecule inhibitor and immunotherapeutic approaches.

\section{SUMMARY: WHERE DO WE GO FROM HERE?}

In this review, we have examined the current status of molecular targeted therapies for malignant gliomas, focusing primarily on lessons learned from targeting the 
EGFR/PI3K/Akt/mTOR signaling pathway in patients. From studying patients in well-designed clinical trials, and integrating this knowledge with rigorous studies in model systems, including mouse models, we have learned: that 1) context-dependent oncogene addiction may determine clinical response; 2) we need to develop ways to monitor adequate target inhibition (particularly with noninvasive assays such as serum-based tests or molecular imaging), and inhibition of relevant downstream effectors, in order to understand the efficacy of targeted agents; 3 ) signal transduction networks are dynamic and interactive, and the cross-talk and feedback between different components of the signaling network may determine response to therapy; and 4) multiple mechanisms may contribute to acquired resistance, including adaptation, possibly additional mutation and selection.

These observations lay out a series of challenges. To improve the outcome of malignant glioma patients treated with targeted therapies, we will need to link targeted agents with molecular diagnostics that not only identify targets, but also anticipate the molecular circuitry of resistance to help guide more effective combination treatments. This will require a suite of new tools to facilitate multiparameter measurement of signaling networks in multiple cell types within the tumor microenvironment, such as between cancer cells and other cell types in the microenvironment (as, for example, vascular endothelial cells play a supportive role in maintaining the self-renewing phenotype of glioblastoma stem cells). ${ }^{68}$ Based on our developing understanding of the communication networks within and between cancer cells, and between cancer cells and their partners in the tumor microenvironment, new combinations of targeted agents (or targeted agents in combination with immunotherapeutic or cytotoxic agents) can be designed to suppress resistance in small, well-designed clinical trials. The good news is that our experience has taught us how much can be learned from studying a small number of patients in great detail. The challenge for successfully treating gliomas with targeted agents is one of translating genomics into functional biology, and functional biology into better therapy for patients. The journey has begun.

\section{REFERENCES}

1. Hanahan D, Weinberg RA. The hallmarks of cancer. Cell 2000; 100:57-70.

2. Bishop JM. Molecular themes in oncogenesis. Cell 1991;64:235248.

3. Bruna A, Darken RS, Rojo F, et al. High TGFbeta-Smad activity confers poor prognosis in glioma patients and promotes cell proliferation depending on the methylation of the PDGF-B gene. Cancer Cell 2007;11:147-160.

4. Yoshida D, Kim K, Noha M, Teramoto A. Hypoxia inducible factor 1-alpha regulates of platelet derived growth factor-B in human glioblastoma cells. J Neurooncol 2006;76:13-21.

5. Arrieta O, Garcia E, Guevara P, et al. Hepatocyte growth factor is associated with poor prognosis of malignant gliomas and is a predictor for recurrence of meningioma. Cancer 2002;94:3210-3218.

6. Koochekpour S, Jeffers M, Rulong S, et al. Met and hepatocyte growth factor/scatter factor expression in human gliomas. Cancer Res 1997;57:5391-5398.

7. Uchinokura S, Miyata S, Fukushima T, et al. Role of hepatocyte growth factor activator (HGF activator) in invasive growth of human glioblastoma cells in vivo. Int J Cancer 2006;118:583592.

8. Reznik TE, Sang Y, Ma Y, et al. Transcription-dependent epidermal growth factor receptor activation by hepatocyte growth factor. Mol Cancer Res 2008;6:139-150.

9. Huang H, Held-Feindt J, Buhl R, Mehdorn HM, Mentlein R. Expression of VEGF and its receptors in different brain tumors. Neurol Res 2005;27:371-377.

10. Ningaraj NS, Rao MK, Black KL. Adenosine 5'-triphosphatesensitive potassium channel-mediated blood-brain tumor barrier permeability increase in a rat brain tumor model. Cancer Res 2003;63:8899-8911.

11. Cerletti A, Drewe J, Fricker G, Eberle AN, Huwyler J. Endocytosis and transcytosis of an immunoliposome-based brain drug delivery system. J Drug Target 2000;8:435-446.

12. Deguchi Y, Kurihara A, Pardridge WM. Retention of biologic activity of human epidermal growth factor following conjugation to a blood-brain barrier drug delivery vector via an extended poly(ethylene glycol) linker. Bioconjug Chem 1999;10:32-37.

13. Badruddoja MA, Black KL. Improving the delivery of therapeutic agents to CNS neoplasms: a clinical review. Front Biosci 2006 11:1466-1478.

14. Fan QW, Cheng C, Knight ZA, et al. EGFR signals to mTOR through PKC and independently of Akt in glioma [Erratum in: Sci Signal 2009;2(60):er4]. Sci Signal 2009;2(55):ra4.

15. Li L, Dutra A, Pak E, et al. EGFRvIII expression and PTEN loss synergistically induce chromosomal instability and glial tumors. Neuro Oncol 2009;11:9-21.

16. Pore N, Liu S, Haas-Kogan DA, O'Rourke DM, Maity A. PTEN mutation and epidermal growth factor receptor activation regulate vascular endothelial growth factor (VEGF) mRNA expression in human glioblastoma cells by transactivating the proximal VEGF promoter. Cancer Res 2003;63:236-241.

17. Cancer Genome Atlas Research Network. Comprehensive genomic characterization defines human glioblastoma genes and core pathways. Nature 2008;455:1061-1068.

18. Parsons DW, Jones S, Zhang X, et al. An integrated genomic analysis of human glioblastoma multiforme. Science 2008;321: 1807-1812.

19. Bachoo RM, Maher EA, Ligon KL, et al. Epidermal growth factor receptor and Ink4a/Arf: convergent mechanisms governing terminal differentiation and transformation along the neural stem cell to astrocyte axis. Cancer Cell 2002;1:269-277.

20. Holland EC. Gliomagenesis: genetic alterations and mouse models. Nat Rev Genet 2001;2:120-129.

21. Shannon P, Sabha N, Lau N, et al. Pathological and molecular progression of astrocytomas in a GFAP:12 V-Ha-Ras mouse astrocytoma model. Am J Pathol 2005;167:859-867.

22. Wei Q, Clarke L, Scheidenhelm DK, et al. High-grade glioma formation results from postnatal Pten loss or mutant epidermal growth factor receptor expression in a transgenic mouse glioma model. Cancer Res 2006;66:7429-7437.

23. Weiss WA, Burns MJ, Hackett C, et al. Genetic determinants of malignancy in a mouse model for oligodendroglioma. Cancer Res 2003;63:1589-1595.

24. Xiao A, Wu H, Pandolfi PP, Louis DN, Van Dyke T. Astrocyte inactivation of the $\mathrm{pRb}$ pathway predisposes mice to malignant astrocytoma development that is accelerated by PTEN mutation. Cancer Cell 2002;1:157-168.

25. Zheng H, Ying H, Yan H, et al. p53 and Pten control neural and glioma stem/progenitor cell renewal and differentiation. Nature 2008;455:1129-1133.

26. Zhu Y, Guignard F, Zhao D, et al. Early inactivation of p53 tumor suppressor gene cooperating with NF1 loss induces malignant astrocytoma. Cancer Cell 2005;8:119-130. 
27. Kwon CH, Zhao D, Chen J, et al. Pten haploinsufficiency accelerates formation of high-grade astrocytomas. Cancer Res 2008; 68:3286-3294.

28. Sarkaria JN, Yang L, Grogan PT, et al. Identification of molecular characteristics correlated with glioblastoma sensitivity to EGFR kinase inhibition through use of an intracranial xenograft test panel. Mol Cancer Ther 2007;6:1167-1174.

29. Choe G, Horvath S, Cloughesy TF, et al. Analysis of the phosphatidylinositol $3^{\prime}$-kinase signaling pathway in glioblastoma patients in vivo. Cancer Res 2003;63:2742-2746.

30. Ermoian RP, Furniss CS, Lamborn KR, et al. Dysregulation of PTEN and protein kinase B is associated with glioma histology and patient survival. Clin Cancer Res 2002;8:1100-1106.

31. Riemenschneider MJ, Betensky RA, Pasedag SM, Louis DN. AKT activation in human glioblastomas enhances proliferation via TSC2 and S6 kinase signaling. Cancer Res 2006;66:56185623.

32. Huang HS, Nagane M, Klingbeil CK, et al. The enhanced tumorigenic activity of a mutant epidermal growth factor receptor common in human cancers is mediated by threshold levels of constitutive tyrosine phosphorylation and unattenuated signaling. J Biol Chem 1997;272:2927-2935.

33. Maruno M, Kovach JS, Kelly PJ, Yanagihara T. Transforming growth factor-alpha, epidermal growth factor receptor, and proliferating potential in benign and malignant gliomas. J Neurosurg 1991;75:97-102.

34. Montgomery RB, Moscatello DK, Wong AJ, Cooper JA, Stahl WL. Differential modulation of mitogen-activated protein (MAP) kinase/extracellular signal-related kinase kinase and MAP kinase activities by a mutant epidermal growth factor receptor. J Biol Chem 1995;270:30562-30566.

35. Samuels V, Barrett JM, Bockman S, Pantazis CG, Allen MB Jr. Immunocytochemical study of transforming growth factor expression in benign and malignant gliomas. Am J Pathol 1989; 134:894-902.

36. Wikstrand CJ, McLendon RE, Friedman AH, Bigner DD. Cell surface localization and density of the tumor-associated variant of the epidermal growth factor receptor, EGFRvIII. Cancer Res 1997;57:4130-4140.

37. Yung WK, Zhang X, Steck PA, Hung MC. Differential amplification of the TGF-alpha gene in human gliomas. Cancer Commun 1990;2:201-205.

38. Yoshimoto K, Dang J, Zhu S, et al. Development of a real-time RT-PCR assay for detecting EGFRvIII in glioblastoma samples. Clin Cancer Res 2008;14:488-493.

39. Huang PH, Mukasa A, Bonavia R, et al. Quantitative analysis of EGFRvIII cellular signaling networks reveals a combinatorial therapeutic strategy for glioblastoma. Proc Natl Acad Sci U S A 2007; $104: 12867-12872$.

40. Frederick L, Eley G, Wang XY, James CD. Analysis of genomic rearrangements associated with EGRFvIII expression suggests involvement of Alu repeat elements. Neuro Oncol 2000;2:159163.

41. Frederick L, Wang XY, Eley G, James CD. Diversity and frequency of epidermal growth factor receptor mutations in human glioblastomas. Cancer Res 2000;60:1383-1387.

42. Lee JC, Vivanco I, Beroukhim R, et al. Epidermal growth factor receptor activation in glioblastoma through novel missense mutations in the extracellular domain. PLoS Med 2006;3:e485.

43. Akbasak A, Sunar-Akbasak B. Oncogenes: cause or consequence in the development of glial tumors. J Neurol Sci 1992;111:119133.

44. Mishima K, Johns TG, Luwor RB, et al. Growth suppression of intracranial xenografted glioblastomas overexpressing mutant epidermal growth factor receptors by systemic administration of monoclonal antibody (mAb) 806, a novel monoclonal antibody directed to the receptor. Cancer Res 2001;61:5349-5354.

45. Yamoutpour F, Bodempudi V, Park SE, et al. Gene silencing for epidermal growth factor receptor variant III induces cell-specific cytotoxicity. Mol Cancer Ther 2008;7:3586-3597.

46. Martens T, Laabs Y, Gunther HS, et al. Inhibition of glioblastoma growth in a highly invasive nude mouse model can be achieved by targeting epidermal growth factor receptor but not vascular endothelial growth factor receptor-2. Clin Cancer Res 2008;14:5447-5458.

47. Haas-Kogan DA, Prados MD, Tihan T, et al. Epidermal growth factor receptor, protein kinase B/Akt, and glioma response to erlotinib. J Natl Cancer Inst 2005;97:880-887.

48. Doherty L, Gigas DC, Kesari S, et al. Pilot study of the combination of EGFR and mTOR inhibitors in recurrent malignant gliomas. Neurology 2006;67:156-158.

49. Mellinghoff IK, Wang MY, Vivanco I, et al. Molecular determinants of the response of glioblastomas to EGFR kinase inhibitors. N Engl J Med 2005;353:2012-2024.

50. Fan QW, Cheng CK, Nicolaides TP, et al. A dual phosphoinositide-3-kinase alpha/mTOR inhibitor cooperates with blockade of epidermal growth factor receptor in PTEN-mutant glioma. Cancer Res 2007;67:7960-7965.

51. Wang MY, Lu KV, Zhu S, et al. Mammalian target of rapamycin inhibition promotes response to epidermal growth factor receptor kinase inhibitors in PTEN-deficient and PTEN-intact glioblastoma cells. Cancer Res 2006;66:7864-7869.

52. Chang SM, Wen P, Cloughesy T, et al. Phase II study of CCI-779 in patients with recurrent glioblastoma multiforme. Invest New Drugs 2005;23:357-361.

53. Cloughesy TF, Yoshimoto K, Nghiemphu P, et al. Antitumor activity of rapamycin in a Phase I trial for patients with recurrent PTEN-deficient glioblastoma. PLoS Med 2008;5:e8.

54. Guertin DA, Sabatini DM. Defining the role of mTOR in cancer. Cancer Cell 2007;12:9-22.

55. Nakamura JL, Garcia E, Pieper RO. S6K1 plays a key role in glial transformation. Cancer Res 2008;68:6516-6523.

56. Carracedo A, Baselga J, Pandolfi PP. Deconstructing feedbacksignaling networks to improve anticancer therapy with mTORC1 inhibitors. Cell Cycle 2008;7:3805-3809.

57. Carracedo A, Ma L, Teruya-Feldstein J, et al. Inhibition of mTORC1 leads to MAPK pathway activation through a PI3Kdependent feedback loop in human cancer. J Clin Invest 2008; 118:3065-3074.

58. Stommel JM, Kimmelman AC, Ying H, et al. Coactivation of receptor tyrosine kinases affects the response of tumor cells to targeted therapies. Science 2007;318:287-290.

59. Hambardzumyan D, Becher OJ, Rosenblum MK, et al. PI3K pathway regulates survival of cancer stem cells residing in the perivascular niche following radiation in medulloblastoma in vivo. Genes Dev 2008;22:436-448.

60. Johannessen TC, Bjerkvig R, Tysnes BB. DNA repair and cancer stem-like cells: potential partners in glioma drug resistance? Cancer Treat Rev 2008;34:558-567.

61. Li Z, Wang H, Eyler CE, Rich JN. Turning cancer stem cells inside-out: an exploration of glioma stem cell signaling pathways. J Biol Chem 2009;

62. Bertrand J, Begaud-Grimaud G, Bessette B, et al. Cancer stem cells from human glioma cell line are resistant to Fas-induced apoptosis. Int J Oncol 2009;34:717-727.

63. Solomon DA, Kim JS, Jenkins S, et al. Identification of $\mathrm{p} 18^{\mathrm{INK} 4 \mathrm{c}}$ as a tumor suppressor gene in glioblastoma multiforme. Cancer Res 2008;68:2564-2569.

64. Yu Y, Jiang X, Schoch BS, et al. Aberrant splicing of cyclindependent kinase-associated protein phosphatase KAP increases proliferation and migration in glioblastoma. Cancer Res 2007;67: $130-138$.

65. Glaser T, Wagenknecht B, Weller M. Identification of p21 as a target of cycloheximide-mediated facilitation of CD95-mediated apoptosis in human malignant glioma cells. Oncogene 2001;20: 4757-4767.

66. Dinca EB, Lu KV, Sarkaria JN, et al. p53 Small-molecule inhibitor enhances temozolomide cytotoxic activity against intracranial glioblastoma xenografts. Cancer Res 2008;68:10034-10039.

67. Parsa AT, Waldron JS, Panner A, et al. Loss of tumor suppressor PTEN function increases B7-H1 expression and immunoresistance in glioma. Nat Med 2007;13:84-88.

68. Gilbertson RJ, Rich JN. Making a tumour's bed: glioblastoma stem cells and the vascular niche. Nat Rev Cancer 2007;7:733736. 
69. Rich JN, Reardon DA, Peery T, et al. Phase II trial of gefitinib in recurrent glioblastoma. J Clin Oncol 2004;22:133-142.

70. Brown PD, Krishnan S, Sarkaria JN, et al. Phase I/II trial of erlotinib and temozolomide with radiation therapy in the treatment of newly diagnosed glioblastoma multiforme: North Central Cancer Treatment Group Study N0177. J Clin Oncol 2008;26: 5603-5609.

71. Brandes AA, Franceschi E, Tosoni A, Hegi ME, Stupp R. Epidermal growth factor receptor inhibitors in neuro-oncology: hopes and disappointments. Clin Cancer Res 2008;14:957-960.

72. Wong TW, Lee FY, Yu C, et al. Preclinical antitumor activity of BMS-599626, a pan-HER kinase inhibitor that inhibits HER1/ HER2 homodimer and heterodimer signaling. Clin Cancer Res 2006;12:6186-6193.

73. Neyns B, Sadones J, Joosens E, et al. A multicenter stratified phase II study of cetuximab for the treatment of patients with recurrent high-grade glioma. J Clin Oncol Meet Abstr 2008;26: 2017 (abstract).

74. Cohenuram M, Saif MW. Panitumumab the first fully human monoclonal antibody: from the bench to the clinic. Anticancer Drugs 2007;18:7-15.

75. Bode U, Buchen S, Janssen G, et al. Results of a phase II trial of h-R3 monoclonal antibody (nimotuzumab) in the treatment of resistant or relapsed high-grade gliomas in children and adolescents. J Clin Oncol Meet Abstr 2006;24:1522 (abstract).

76. Bode U, Buchen S, Warmuth-Metz M, et al. Final report of a phase II trial of nimotuzumab in the treatment of refractory and relapsed high-grade gliomas in children and adolescents. J Clin Oncol Meet Abstr 2007;25:2006 (abstract).

77. Schmiedel J, Blaukat A, Li S, Knochel T, Ferguson KM. Matuzumab binding to EGFR prevents the conformational rearrangement required for dimerization. Cancer Cell 2008;13:365-373.

78. Lammerts van Bueren JJ, Bleeker WK, Brannstrom A, et al. The antibody zalutumumab inhibits epidermal growth factor receptor signaling by limiting intra- and intermolecular flexibility. Proc Natl Acad Sci U S A 2008;105:6109-6114.

79. Kuenen B, Witteveen E, Ruijter R, et al. A phase I study of IMC-11F8, a fully human anti-epidermal growth factor receptor (EGFR) IgG1 monoclonal antibody in patients with solid tumors: interim results. ASCO Meet Abstr 2006;24:3024 (abstract).

80. Tabernero J, Sastre Valera J, Delaunoit T, et al. A phase II multicenter study evaluating the efficacy and safety of IMC-11F8, a recombinant human IgG1 anti-epidermal growth factor receptor (EGFR) monoclonal antibody (Mab), combined with 5-FU/FA and oxaliplatin (mFOLFOX-6) as first-line therapy. ASCO Meet Abstr 2008;26:4066 (abstract).

81. Johns TG, Perera RM, Vernes SC, et al. The efficacy of epidermal growth factor receptor-specific antibodies against glioma xenografts is influenced by receptor levels, activation status, and heterodimerization. Clin Cancer Res 2007;13:1911-1925.

82. Mineo JF, Bordron A, Quintin-Roue I, et al. Recombinant humanised anti-HER2/neu antibody (Herceptin) induces cellular death of glioblastomas. Br J Cancer 2004;91:1195-1199.

83. Beltran PJ, Mitchell P, Moody G, et al. Effect of AMG 479 on anti-tumor effects of gemcitabine and erlotinib against pancreatic carcinoma xenograft models. ASCO Meet Abstr 2008;26:4617 (abstract)

84. Rowinsky EK, Youssoufian H, Tonra JR, et al. IMC-A12, a human IgG1 monoclonal antibody to the insulin-like growth factor I receptor. Clin Cancer Res 2007;13:5549s-5555s.

85. Higano CS, Yu EY, Whiting SH, et al. A phase I, first in man study of weekly IMC-A12, a fully human insulin like growth factor-I receptor IgG1 monoclonal antibody, in patients with advanced solid tumors. J Clin Oncol Meet Abstr 2007;25:3505 (abstract)

86. Karp DD, Paz-Ares LG, Novello S, et al. High activity of the anti-IGF-IR antibody CP-751,871 in combination with paclitaxel and carboplatin in squamous NSCLC. ASCO Meet Abstr 2008; 26:8015 (abstract).

87. Cohen BD, Baker DA, Soderstrom C, et al. Combination therapy enhances the inhibition of tumor growth with the fully human anti-type 1 insulin-like growth factor receptor monoclonal antibody CP-751,871. Clin Cancer Res 2005;11:2063-2073.
88. Matsumoto K, Nakamura T, Sakai K. Hepatocyte growth factor and Met in tumor biology and therapeutic approach with NK4. Proteomics 2008;8:3360-3370.

89. Mazzone M, Basilico C, Cavassa S, et al. An uncleavable form of pro-scatter factor suppresses tumor growth and dissemination in mice. J Clin Invest 2004;114:1418-1432.

90. Kong-Beltran M, Stamos J, Wickramasinghe D. The Sema domain of Met is necessary for receptor dimerization and activation. Cancer Cell 2004;6:75-84

91. Michieli P, Mazzone M, Basilico C, et al. Targeting the tumor and its microenvironment by a dual-function decoy Met receptor. Cancer Cell 2004;6:61-73.

92. Compugen. CGEN-241: soluble variants of MET. Available at: http://www.cgen.com/data/uploads/Pdf/CGEN-241\%20update\% 20September\%204\%2008.pdf. Accessed May 29, 2009.

93. Kim KJ, Wang L, Su YC, et al. Systemic anti-hepatocyte growth factor monoclonal antibody therapy induces the regression of intracranial glioma xenografts. Clin Cancer Res 2006;12:12921298.

94. Jun HT, Sun J, Rex K, et al. AMG 102, a fully human antihepatocyte growth factor/scatter factor neutralizing antibody, enhances the efficacy of temozolomide or docetaxel in U-87 MG cells and xenografts. Clin Cancer Res 2007;13:6735-6742.

95. Martens T, Schmidt NO, Eckerich C, et al. A novel one-armed anti-c-Met antibody inhibits glioblastoma growth in vivo. Clin Cancer Res 2006;12:6144-6152.

96. Tseng JR, Kang KW, Dandekar M, et al. Preclinical efficacy of the c-Met inhibitor CE-355621 in a U87 MG mouse xenograft model evaluated by ${ }^{18}$ F-FDG small-animal PET. J Nucl Med 2008;49:129-134.

97. Petrelli A, Circosta P, Granziero L, et al. Ab-induced ectodomain shedding mediates hepatocyte growth factor receptor down-regulation and hampers biological activity. Proc Natl Acad Sci U S A 2006;103:5090-5095.

98. Bellon SF, Kaplan-Lefko P, Yang Y, et al. c-Met inhibitors with novel binding mode show activity against several hereditary papillary renal cell carcinoma-related mutations. J Biol Chem 2008; 283:2675-2683

99. Garcia A, Rosen L, Cunningham CC, et al. Phase 1 study of ARQ 197, a selective inhibitor of the c-Met RTK in patients with metastatic solid tumors reaches recommended phase 2 dose J Clin Oncol Meet Abstr 2007;25:3525 (abstract).

100. Yap TA, Harris D, Barriuso J, et al. Phase I trial to determine the dose range for the c-Met inhibitor ARQ 197 that inhibits c-Met and FAK phosphorylation, when administered by an oral twicea-day schedule. J Clin Oncol Meet Abstr 2008;26:3584 (abstract).

101. Camacho LH, Moulder SL, LoRusso PM, et al. First in human phase I study of MK-2461, a small molecule inhibitor of c-Met, for patients with advanced solid tumors. J Clin Oncol Meet Abstr 2008;26:14657 (abstract).

102. Welsh J, Mahadevan D, Bearss D, Stea B. Sensitization of a glioblastoma multiforme (GBM) cell line by MP470: a novel c-Met antagonist. Int J Radiat Oncol Biol Phys 2007;69:S100 (abstract).

103. Zou HY, Li Q, Lee JH, et al. An orally available small-molecule inhibitor of c-Met, PF-2341066, exhibits cytoreductive antitumor efficacy through antiproliferative and antiangiogenic mechanisms. Cancer Res 2007;67:4408-4417.

104. Christensen JG, Schreck R, Burrows J, et al. A selective small molecule inhibitor of c-Met kinase inhibits c-Met-dependent phenotypes in vitro and exhibits cytoreductive antitumor activity in vivo. Cancer Res 2003;63:7345-7355.

105. Berthou S, Aebersold DM, Schmidt LS, et al. The Met kinase inhibitor SU11274 exhibits a selective inhibition pattern toward different receptor mutated variants. Oncogene 2004;23: 5387-5393.

106. Sattler M, Pride YB, Ma P, et al. A novel small molecule met inhibitor induces apoptosis in cells transformed by the oncogenic TPR-MET tyrosine kinase. Cancer Res 2003;63:5462-5469.

107. Ross RW, Stein M, Sarantopoulos J, et al. A phase II study of the c-Met RTK inhibitor XL880 in patients (pts) with papillary renalcell carcinoma (PRC). J Clin Oncol Meet Abstr 2007;25:15601 (abstract). 
108. Salgia R, Sherman S, Hong DS, et al. A phase I study of XL184, a RET, VEGFR2, and MET kinase inhibitor, in patients (pts) with advanced malignancies, including pts with medullary thyroid cancer (MTC). J Clin Oncol Meet Abstr 2008;26:3522 (abstract).

109. Du J, Bernasconi P, Clauser KR, et al. Bead-based profiling of tyrosine kinase phosphorylation identifies SRC as a potential target for glioblastoma therapy. Nat Biotechnol 2009;27:77-83.

110. Raymond E, Brandes AA, Dittrich C, et al. Phase II study of imatinib in patients with recurrent gliomas of various histologies: a European Organisation for Research and Treatment of Cancer Brain Tumor Group study. J Clin Oncol 2008;26:4659-4665.

111. Reardon DA, Egorin MJ, Quinn JA, et al. Phase II study of imatinib mesylate plus hydroxyurea in adults with recurrent glioblastoma multiforme. J Clin Oncol 2005;23:9359-9368.

112. Wen PY, Yung WK, Lamborn KR, et al. Phase I/II study of imatinib mesylate for recurrent malignant gliomas: North American Brain Tumor Consortium Study 99-08. Clin Cancer Res 2006;12:4899-4907.

113. Reardon DA, Egorin MJ, Desjardins A, et al. Phase I pharmacokinetic study of the vascular endothelial growth factor receptor tyrosine kinase inhibitor vatalanib (PTK787) plus imatinib and hydroxyurea for malignant glioma. Cancer 2009;

114. Vredenburgh JJ, Desjardins A, Herndon JE 2nd, et al. Bevacizumab plus irinotecan in recurrent glioblastoma multiforme. J Clin Oncol 2007;25:4722-4729.

115. Kreisl TN, Kim L, Moore K, et al. Phase II trial of single-agent bevacizumab followed by bevacizumab plus irinotecan at tumor progression in recurrent glioblastoma. J Clin Oncol 2009;27:740745.

116. Gomez-Manzano C, Holash J, Fueyo J, et al. VEGF Trap induces antiglioma effect at different stages of disease. Neuro Oncol 2008;10:940-945.

117. De Groot JF, Wen PY, Lamborn K, et al. Phase II single arm trial of aflibercept in patients with recurrent temozolomide- resistant glioblastoma: NABTC 0601. J Clin Oncol Meet Abstr 2008;26:2020 (abstract).

118. Wedge SR, Kendrew J, Hennequin LF, et al. AZD2171: a highly potent, orally bioavailable, vascular endothelial growth factor receptor-2 tyrosine kinase inhibitor for the treatment of cancer. Cancer Res 2005;65:4389-4400.

119. Batchelor TT, Sorensen AG, di Tomaso E, et al. AZD2171, a pan-VEGF receptor tyrosine kinase inhibitor, normalizes tumor vasculature and alleviates edema in glioblastoma patients. Cancer Cell 2007;11:83-95.

120. Podar K, Tonon G, Sattler M, et al. The small-molecule VEGF receptor inhibitor pazopanib (GW786034B) targets both tumor and endothelial cells in multiple myeloma. Proc Natl Acad Sci U S A 2006;103:19478-19483.

121. Adnane L, Trail PA, Taylor I, et al. Sorafenib (BAY 43-9006, Nexavar), a dual-action inhibitor that targets RAF/MEK/ERK pathway in tumor cells and tyrosine kinases VEGFR/PDGFR in tumor vasculature. Methods Enzymol 2006;407:597-612.

122. Wedge SR, Ogilvie DJ, Dukes M, et al. ZD6474 inhibits vascular endothelial growth factor signaling, angiogenesis, and tumor growth following oral administration. Cancer Res 2002;62:46454655.

123. Heymach JV, Paz-Ares L, De Braud F, et al. Randomized Phase II Study of Vandetanib alone or with paclitaxel and carboplatin as first-line treatment for advanced non-small-cell lung cancer. J Clin Oncol 2008;26:5407-5415.

124. Wells SA Jr, Gosnell JE, Gagel RF, et al. Vandetanib in metastatic hereditary medullary thyroid cancer: follow-up results of an open-label phase II trial. ASCO Meet Abstr 2007;25:6018.

125. Kirkpatrick JP, Rich JN, Vredenburgh JJ, et al. Final report: Phase I trial of imatinib mesylate, hydroxyurea, and vatalanib for patients with recurrent malignant glioma (MG). ASCO Meet Abstr 2008;26:2057 (abstract). 